\title{
An updated review on probiotics as an alternative of antibiotics in poultry - A review
}

\author{
Muhammad Umar Yaqoob ${ }^{1}$, Geng Wang ${ }^{1}$, and Minqi Wang ${ }^{1, *}$
}

* Corresponding Author: Minqi Wang
Tel: +86-571-88982112,
Fax: +86-571-88982650,
E-mail: wangmq@zju.edu.cn

${ }^{1}$ College of Animal Science, Zhejiang University, Key Laboratory of Animal Nutrition and Feed Science (Eastern China), Ministry of Agriculture, Hangzhou 310058, China

\section{ORCID}

Muhammad Umar Yaqoob

https://orcid.org/0000-0003-4072-2182

Geng Wang

https://orcid.org/0000-0001-6896-3522

Minqi Wang

https://orcid.org/0000-0001-5658-2896

Submitted Oct 28, 2021; Revised Dec 21, 2021; Accepted Jan 18, 2022

\begin{abstract}
Antibiotics used to be supplemented to animal feeds as growth promoter and as an effective strategy to reduce the burden of pathogenic bacteria present in the gastro-intestinal tract. However, in-feed antibiotics also kill bacteria that may be beneficial to the animal. Secondly, unrestricted use of antibiotics enhanced the antibiotic resistance in pathogenic bacteria. To overcome above problems, scientists are taking a great deal of measures to develop alternatives of antibiotics. There is convincing evidence that probiotics could replace in-feed antibiotics in poultry production. Because they have beneficial effects on growth performance, meat quality, bone health and eggshell quality in poultry. Better immune responses, healthier intestinal microflora and morphology which help the birds to resist against disease attack were also identified with the supplementation of probiotics. Probiotics establish cross-feeding between different bacterial strains of gut ecosystem and reduce the blood cholesterol level via bile salt hydrolase activity. The action mode of probiotics was also updated according to recently published literatures, i.e antimicrobial substances generation or toxin reduction. This comprehensive review of probiotics is aimed to highlight the beneficial effects of probiotics as a potential alternative strategy to replace the antibiotics in poultry.
\end{abstract}

Keywords: Growth; Immunity; Intestinal Health; Poultry

\section{INTRODUCTION}

Since they were discovered antibiotics (ABs) have been used for prevention and treatment of infectious diseases and when added at sub-therapeutic level in diet as a growth promoter in many animal species. Antibiotics also performed significant role in the improvement and success of animal husbandry. Chicken is the only species with highest population worldwide reared as food animal and highest concentration with different strains, ABs are used in poultry farming [1]. When ABs are used in any system, they kill the susceptible bacterial leaving behind some resistant strains, which increase in number with the passage of time and might become the cause of resistant genes transfer to other bacteria [2]. These resistant bacteria may transfer from one host to other, directly, or indirectly and lower the effectiveness of drugs and become the cause of antibiotics resistance (ABR), [3]. In this way $A B s$ exhibit negative effects on animals and human when used continuously at subtherapeutic for long time or used in excess [4]. ABR in bacteria could ether be inherent directly or acquired from other species of bacteria in the environment [5] and develops by different ways such as lowering the permeability of bacterial cell membrane, developing changes in binding sites where the ABs attach in bacteria or/and alteration in enzyme production [6]. There are several bacteria which have developed ABR due to improper use of ABs. Staphylococcus species which commonly affect the chicken and cause pododer- 
matitis, staphylococcosis, and septicemia have been developed ABR against $\beta$-lactams [7]. Some Staphylococcus species also developed ABR against tetracycline and oxacillin $[8,9]$. Similarly, Pseudomonas aeruginosa (P. aeruginosa) has developed ABR against carbapenems, quinolones, aminoglycoside, cephalosporins, penicillins and monobactam [10]. P. aeruginosa obtained from chicken in Pakistan was $100 \%$ resistant to colistin, ceftriaxone, erythromycin, meropenem and ciprofloxacin [11]. In addition, Escherichia coli (E. coli) is now resistant to most commonly used drug in poultry i.e. tetracycline [12]. Different Salmonella spp. have developed ABR against ampicillin, tetracycline, trimethoprim, ciprofloxacin and sulfamethazole [13]. Similarly, Campylobacter jejuni and $E$. coli have also been reported to resistant to erythromycin and tetracycline [14].

Keeping in view $\mathrm{ABR}$ and other negative effects caused by unrestricted use of $A B s$, the European Union banned the use of ABs in animals feed in 2006 [15]. Similarly, the US Food and Drug Administration published its rule for judicious use of ABs only for treatment of animals under Veterinary Feed Directive in 2015. The limited use or ban on the use of in feed ABs increase the demand of alternatives to avoid the decline in the production performance of animals and economic losses. During last two decades, nutritionist and pharmacists have worked to develop some replacements to retain or enhance animal health and performance. Many alternatives are being used and experimentally checked for their effectiveness for animals and humans. One of the alternatives is probiotics.

Probiotics can be defined as the live microorganisms which have beneficial effects on the host when fed in adequate amounts [16]. They are considered as one of the best alternatives because of several useful aspects, both for humans and animals. They can be used to reduce the harmful bacteria and to enhance the growth and productivity of animals by improving digestion and absorption of nutrients [17]. Probiotics includes the microorganisms of different species of bacteria, fungi, or yeast. Some probiotics of bacterial origin (Lactobacillus, Bacillus subtilis [B. subtilis], Bifidobacterium, and Streptococcus) also have antimicrobial activity towards some pathogenic bacteria like E. coli, Clostridium perfringens, Staphylococcus aureus, and Salmonella typhimurium etc. [18]. There is need of proper selection of probiotics regarding dose and type to avoid the losses and to get valuable benefits. This article reviews the effect of probiotics (single and in combination) on growth, meat quality, bone health, eggshell quality, immunity, intestinal microflora and morphology in poultry as well as updates action mode of probioitcs.

\section{CONCEPT OF PROBIOTICS, COMMON VARIETIES AND SELECTION}

"Probiotics could be mono or mixed cultures of the live microorganisms which have some beneficial effects on the host when fed to them in adequate amount" [16]. Angelakis, [19] stated some characteristics of a good probiotic i.e., it should not be pathogenic or toxic in nature, should have positive impact on host animal, should survive in gut environment, should be viable and remain viable under stored condition. Bifidobacterium, Bacillus, Streptococcus, Lactobacillusa and Lactococcus are the genera commonly used as probiotics in poultry [20]. Other commonly used probiotics are L. casei, B. subtilis, L. acidophilus, L. bulgaricus, L. plantarum, L. lactis, Enterococcus faecalis, E. faecium, Bifidobacterium spp., Saccharomyces cerevisiae (S. cerevisiae), and Aspergillus oryzae. Much work has been done on Bifidobacterium spp. in humans as well. Enterococcus spp., Bacillus spp., and Saccharomyces spp. are generally used probiotics in livestock [21]. Probiotics could be a single or multi strains and may be given in combination with other feed additives through feed or water. It is generally accepted that multiple strains probiotics are more beneficial than single stain because multiple strains have synergistic effects [22]. Probiotics exist in different forms such as granules, power, liquid, paste and gel etc. Dry form is better for storage and gastric environment [23]. Selection criteria for probiotics includes following characteristics: survival under gastrointestinal conditions, competitive exclusion of pathogenic bacteria, ability to stay/attach to mucosa of gastrointestinal tract [20] and ability to survive under different feed processing conditions [24].

\section{PROBIOTICS ON GROWTH PERFORMANCE AND MEAT QUALITY}

Though the mechanism of probiotics to improve the growth performance is not fully understood, studies suggested that they are growth enhancers (Table 1) and ameliorate the effects of disease attack and stress. Growth performance of broilers is improved by using single and multiple strains of Lactobacillus spp. [25-27]. Pediococcus acidilactici (P. acidilactici) significantly improved the feed intake, weight gain (WG), and feed conversion ratio (FCR) in broilers [28]. Significant increase in WG was detected using different types of probiotics $[29,30]$. L. fermentum was reported to have various results in combination with different probiotics, no significant effect was observed with S. cerevisiae [31] and slight increase in body weight of broilers with E. faecium [32]. B. subtilis and E. faecium significantly improved final body WG and FCR [33,34]. Different strains of B. subtilis alone or in combination of $E$. faecium significantly improved the growth performance of broilers and layer $[33,35,36]$. However, contradictory results were found by using Lactobacillus spp. ( $L$. crispatus, L. ohnsonii, L. salivarius, and some unidentified Lactobacillus spp.), [37]. Feeding multiple strains of probiotics 
Table 1. Effect of probiotics on growth performance of poultry

\begin{tabular}{|c|c|c|c|c|c|c|}
\hline $\mathrm{Sr}$ & Probiotic & Animal & Inclusion level & $\begin{array}{l}\text { Duration } \\
\text { (d) }\end{array}$ & Growth performance & Reference \\
\hline 1 & $\begin{array}{l}\text { L. plantarum strain } \\
\text { IMAU10120 (LP-8) }\end{array}$ & Broiler & $2 \times 10^{6} \mathrm{cfu} / \mathrm{mL}$ & 42 & Improved FCR & [25] \\
\hline 3 & $\begin{array}{l}\text { L. agilis JCM } 1048 \text { and L. salivarius subsp. } \\
\text { salicinius JCM } 1230\end{array}$ & Broiler & & 40 & Significant increase in weight gain & {$[27]$} \\
\hline 4 & Pediococcus acidilactici MA18/5M & Broiler & 0.8 to $1.6 \mathrm{~g}$ & 42 & $\begin{array}{l}\text { Significant improvement in overall } \\
\text { growth performance }\end{array}$ & [28] \\
\hline 5 & 3 Bacillus subtilis strains & Broiler & $\begin{array}{l}3 \times 10^{5} \mathrm{cfu} / \mathrm{g} \text { of fin- } \\
\text { ished feed }\end{array}$ & 41 & Improved overall body weight gain & {$[29]$} \\
\hline 6 & $\begin{array}{l}\text { A. oryzae, B. bifidum, B. thermophilus, } C \text {. } \\
\text { pintolopessi, E. faecium, L. acidophilus, L. } \\
\text { bulgaricus, L. plantarum and L. rhamnosus }\end{array}$ & Broiler & $\begin{array}{l}2 \mathrm{gm} / 10 \text { liters drinking } \\
\text { water }\end{array}$ & 42 & $\begin{array}{l}\text { Significant increase in WG, breast } \\
\text { and leg meat yield }\end{array}$ & [30] \\
\hline 9 & B. subtilis and E. faecium & Layer & 1 and $2 \mathrm{~g} / \mathrm{kg}$ of feed & 70 & $\begin{array}{l}\text { Significant effect on final body } \\
\text { weight gain and FCR }\end{array}$ & [33] \\
\hline 10 & S. boulardii and B. subtilis B10 & Broiler & $1 \times 10^{8} \mathrm{cfu} / \mathrm{kg}$ of feed & 72 & $\begin{array}{l}\text { Significant improvement in live } \\
\text { body weight }\end{array}$ & [34] \\
\hline 11 & B. subtilis C-3102 & Broiler & $0.1 \%$ of diet & 42 & $\begin{array}{l}\text { Significantly increased body weight } \\
\text { and decreased FCR }\end{array}$ & [35] \\
\hline 12 & $\begin{array}{l}\text { B. subtilis } \\
\text { PB6 (ATCC-PTA 6737) }\end{array}$ & Broiler & $5 \times 10^{11} \mathrm{cfu} / \mathrm{kg}$ feed & 35 & FCR was significantly improved & {$[36]$} \\
\hline 13 & $\begin{array}{l}\text { L. ohnsonii, (No.709) L. crispatus (No.697) L. } \\
\text { salivarius (No.461) and unidentified Lacto- } \\
\text { bacillus spp. }\end{array}$ & Broiler & & 42 & $\begin{array}{l}\text { No significant effect on growth } \\
\text { performance }\end{array}$ & [37] \\
\hline
\end{tabular}

FCR, feed conversion ratio; WG, weight gain; cfu, colony forming unit.

(E. faecium, Bifidobacterium animals, P. acidilactici, L. reuteri, and L. salivarius) significantly improved WG, FCR, and production efficiency factor [38]. Many meta-analyses have also been done to evaluate the effect of probiotics on broilers and other animals. A meta-analysis was conducted by Faria-Filho et al [39] to observe the response of broilers by feeding 12 different probiotics. In this analysis, data was collected form 27 studies involving 30,146 broilers. They concluded that WG and FCR was improved by probiotics feeding. A more comprehensive meta-analysis comprising studies of 32 years were performed by Blajman et al [40]. They stated that probiotics feeding had positive effect on WG and FCR. They also suggested no difference in using single or multi-strain probiotics, but probiotics provided in water were more effective than via feed. Depending upon the health status, boilers respond differently to different probiotics. Immune modulation and balancing of gut microbiota are two possible reasons for improving growth performance of broilers by probiotics feeding. Probiotics prevent the proliferation of pathogenic bacteria by decreasing the intestinal $\mathrm{pH}$ through production of short chain fatty acids and maintain the equilibrium between beneficial and pathogenic bacteria which is essentially required of gut health and proper growth performance of broilers.

Variable results are found in literature about the effect of probiotics on meat quality in broilers. Improvement in meat flavor was observed by feeding broilers on B. subtilis and $B$. licheniformis [41] however, no significant effect of probiotics was found on sensory attributes of meat in another study [42]. Mahajan et al [43] stated that meat sensory characteristics (overall acceptability, texture, appearance, and juiciness) were positively affected by probiotics feeding. In addition, Pelicano et al [44] stated that probiotics feeding improved the meat flavor. Previous results were also supported by 
Ceslovas et al [45], they found improved meat quality and tenderness by probiotics. Contradictions in the results might be due to use of different type or dose of probiotics, duration of experiment or age of birds at which the probiotics were fed to the birds.

\section{PROBIOTICS ON BONE HEALTH AND EGGSHELL QUALITY}

Previous studies confirmed that probiotics supplementation also has positive effects on bone health in poultry. Probiotics improved the gut health, enhanced the absorption capacity of intestine and bioavailability of minerals by different ways. Most of the studies presented the effect of various probiotics on tibia bone, might be since tibia is more prone to skeletal problems. Bacillus subtilis improved the tibia ash and ash $\mathrm{Ca}$ percentage [46]; Enterococcus faecium and lactic acid producing bacteria improved different tibia indexes including tibia Ca and Ca percentage [47]; B. subtilis and B. licheniformis improved tibia thickness, ash and P percentage [48]; Lactobacillus sporogenes enhanced tibia breaking strength and ash percentage [49] whereas Clostridium butyricum and B. subtilis also enhanced tibia breaking strength, ash contents and tibia weight/length index [50] in broilers. Additionally, probiotics also have the ability to protect the bone under different pathological conditions as described by Sadeghi [46], that supplementation of B. subtilis in broilers challenged with Salmonella enteritidis (S. enteritidis) improved the tibia bone minerals contents including $\mathrm{Ca}$ at 21 days of age. Probiotics also reduce the negative effects of low $\mathrm{Ca}$ diet in broilers [50]. Another study indicated that supplementation of B. subtilis in diet of laying hens (at 0.5 or $1.0 \mathrm{~g} / \mathrm{kg}$ of feed) boosted the tibia indexes such as length, weight, density, and ash contents [51]. Similarly, B. subtilis feeding in laying hens also decreased the number of unmarketable eggs [52]. Furthermore, different probiotics also improved the eggshell quality in laying hens [53].

Basic reason underlying improved bone health by probi- otics feeding is enhanced Ca absorption by different ways (Figure 1). An in vitro study reported that $L$. salivarius enhanced trans-epithelial Ca transport in human cells, while in vivo study supported this result as $\mathrm{Ca}$ and $\mathrm{P}$ concentration was higher in probiotics supplemented rats than control group [54]. Probiotics increase Ca bioavailability through different ways such as they produce phytase having ability to degrade phytate and release bounded minerals like $\mathrm{Ca}$ and $\mathrm{P}$ [55]. As mentioned in another section that probiotics positively affect the gut morphology and increase the absorption area of intestine by increasing villus length and villus length to crypt depth ratio. So, higher absorption area increases the rate of minerals absorption. Another possible way of increasing mineral absorption is reduced intestinal $\mathrm{pH}$ due to short chain fatty acids produced by probiotics. Acidic environments favor the absorption of $\mathrm{Ca}$ [56].

\section{PROBIOTICS ON IMMUNE RESPONSE}

Probiotics as an alternative to $\mathrm{ABs}$ are considered to improve the health status and immunity in poultry birds (Table 2). Bai et al [31] demonstrated that $\mathrm{T}$ cell immune system was improved by probiotics (combined: L. fermentum and S. cerevisiae) without compromising the growth performance of broilers. It is also proved that Lactobacillus (LAB) influenced the chemokine gene expression and cytokines production in chicken [57]. $L A B$ improved the production of anti- and pro-inflammatory cytokines in the intestinal epithelium of broiler chicken. The cytokines production influences the overall immune system. Increase in antibody production by $\beta$-lymphocytes is another potential mechanism of $L A B$ in improving the immunity in broiler. L. fermentum improved the blood $\mathrm{CD}^{+}$lymphocyte value as well as interferon- $\gamma$ and tumor necrosis factor- $a$ expression in the ileum. Waititu et al [58] fed a mixture of three Bacillus subtilis strains (BSS) and Propionibacterium acidipropionici (PA) to broilers and found downregulation of ileal expression of different cytokines by PA and interleukin-10 (IL-10) in the spleen, IL-2,

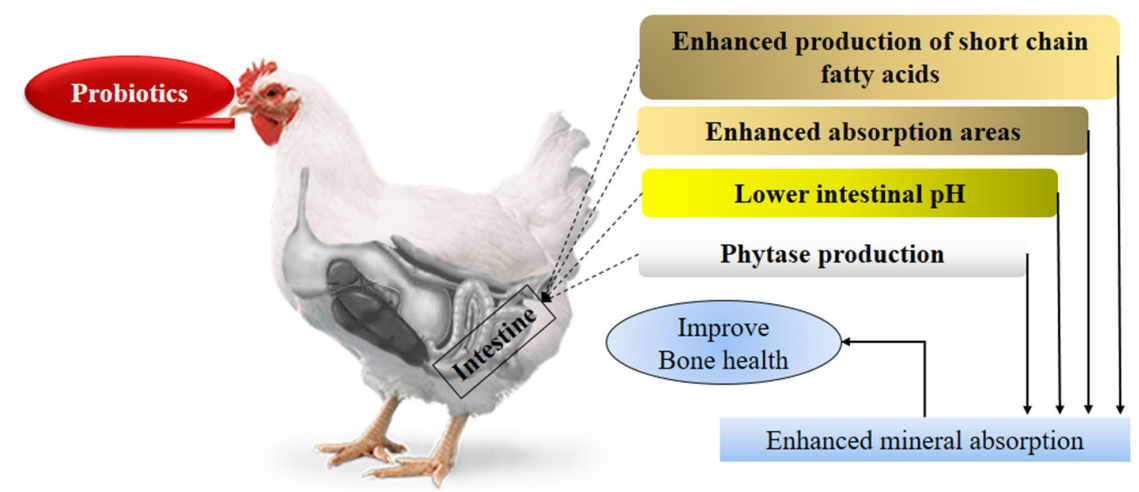

Figure 1. Mechanisms underlying improved bone health by probiotics feeding. 
Table 2. Effect of probiotics on immune response of poultry

\begin{tabular}{|c|c|c|c|c|c|c|}
\hline $\mathrm{Sr}$ & Probiotic & Animal & Inclusion level & Duration & Immune response & Reference \\
\hline 1 & L. plantarum strain IMAU10120 & Broiler & $2 \times 10^{6} \mathrm{cfu} / \mathrm{mL}$ & 42 days & $\begin{array}{l}\text { Induced the highest level of immunity } \\
\text { response }\end{array}$ & [25] \\
\hline 2 & $\begin{array}{l}\text { A. oryzae, B. bifidum, B. thermophilus, } \\
\text { C. pintolopessi, E. faecium, L. acidophi- } \\
\text { lus, L. bulgaricus, L. plantarum and L. } \\
\text { rhamnosus }\end{array}$ & Broiler & $\begin{array}{l}2 \mathrm{gm} / 10 \text { liters of } \\
\text { drinking water }\end{array}$ & 42 days & $\begin{array}{l}\text { Significantly enhance the antibodies } \\
\text { production and weight of immune } \\
\text { organs }\end{array}$ & [30] \\
\hline 3 & $\begin{array}{l}\text { L. fermentum } \\
\text { S. cerevisiae }\end{array}$ & Broiler & $\begin{array}{l}10^{7} \mathrm{cfu} / \mathrm{g} \\
2 \times 10^{6} \mathrm{cfu} / \mathrm{g}\end{array}$ & 42 days & $\begin{array}{l}\text { Significant increase in } \mathrm{CD}^{+}, \mathrm{CD}^{+} \text {and } \\
\mathrm{CD}^{+} \text {levels }\end{array}$ & [31] \\
\hline 5 & S. boulardii and B. subtilis B10 & Broiler & $10^{8} \mathrm{cfu} / \mathrm{kg}$ of feed & 72 days & $\begin{array}{l}\text { Significant improvement in inflamma- } \\
\text { tory and anti-inflammatory cytokines, } \\
\text { IgA+ cells in jejunum, intestinal cy- } \\
\text { tokines IL-6, tumor necrosis factor- } \alpha \text {, } \\
\text { IL-10 and transforming growth factor- } \beta\end{array}$ & [34] \\
\hline 8 & $\begin{array}{l}\text { Blend of } 3 \text { Bacillus substilis strains } \\
\text { (BSS) and Propionibacterium acidipro- } \\
\text { pionici (PA) }\end{array}$ & Broiler & $7.5 \times 10^{4} \mathrm{cfu} / \mathrm{g}$ & 21 days & $\begin{array}{l}\text { PA downregulated ileal expression of } \\
\text { TLR-2b, IL-2, IL-4, IL-6, IL- 10, and IL-13, } \\
\text { whereas BSS downregulated TLR-2b, } \\
\text { IL-2, IL-4, and IL-6 in all } 3 \text { tissues }\end{array}$ & [58] \\
\hline 9 & E. faecium & Layer & $4 \times 10^{8} \mathrm{cfu} / \mathrm{kg}$ & 48 days & Improvement in IgA production & [59] \\
\hline 10 & $\begin{array}{l}\text { L. acidophilus, B. bifidum and S. faeca- } \\
\text { lis }\end{array}$ & Broiler & $\begin{array}{l}10^{6} \text { bacteria/chick } \\
\text { on day of hatching }\end{array}$ & 14 days & $\begin{array}{l}\text { Enhanced systemic and local antibod- } \\
\text { ies production }\end{array}$ & [60] \\
\hline 11 & Lactobacillus spp. & Broiler & $1 \mathrm{~g} / \mathrm{kg}$ feed & 35 days & $\begin{array}{l}\text { Increase intestinal intraepithelial } \\
\text { lymphocyte expressing the surface } \\
\text { markers CD3, CD4 and CD8 }\end{array}$ & [61] \\
\hline
\end{tabular}

cfu, colony forming unit; CD, cluster of differentiation molecules; Ig, immunoglobulin; IL, interleukin; ND, Newcastle disease; IB, Infectious bronchitis; IBD, Infectious bursal disease ; IgA, immunoglobulin A; PA, Propionibacterium acidipropionici; TLR, toll like receptor; IFN, interferon.

IL-4, IL-6, and toll like receptor-2b in all examined tissues by BSS, whereas IL-13 was upregulated in spleen by BSS. Kabir et al [30] found significant increase in the antibodies concentration and weight of immune organs (bursa and spleen) of broilers by using Protexin Boost (a mixture of different probiotics) at the rate of $0.2 \mathrm{~g} /$ liters of drinking water.

E. faecium improved immunoglobulin A production in layers [59]. Similarly, findings of Haghighi et al [60] also suggested the enhanced systemic immunity and local antibodies production in broilers at 14 days post hatching by feeding $L A B$ in combination with B. bifidum and S. faecalis. $L A B$ also increase intestinal intraepithelial lymphocyte expression of the surface markers $\mathrm{CD}^{+}, \mathrm{CD}^{+}$, and $\mathrm{CD} 8^{+}$in broilers [61]. L. fermentum $\left(10^{7} \mathrm{cfu} / \mathrm{g}\right)$ with $S$. cerevisiae $(2 \times$ $\left.10^{6} \mathrm{cfu} / \mathrm{g}\right)$ significantly increased $\mathrm{CD} 8^{+}, \mathrm{CD}^{+}$, and $\mathrm{CD} 4^{+}$ levels in broilers [31]. Hatab et al [33] found improved antibody production against Newcastle disease virus in layers birds by B. subtilis and E. faecium. Similarly, B. subtilis feed- ing increased the antibody titers levels in broilers against Newcastle disease, Infectious bronchitis, and Infectious bursal disease virus [35].

\section{PROBIOTICS ON INTESTINAL MICROBIOFLORA AND MORPHOLOGY}

Animal health status and growth performance are directly linked with gut health and its microflora. A healthy gut is more defensive against pathogenic microorganisms and works more efficiently for nutrients absorption. A stable microflora is also required to avoid infections in the gut which helps the animals in different ways, by avoiding the colonization of pathogens by bacterial antagonism or occupying the attachment site in gut and interfering with bacterial activities. The intestinal microflora is quite stable but influenced by different environmental factors and health status of animals. Environmental factors include diet, hygiene conditions and stress. 
The most important factor which affects the gut microflora is diet. Probiotics are generally applied to regulate the gut microbiota [62] (Figure 2). Similarly, gut morphological parameters also have significant importance towards health and performance of poultry birds and animals as higher villus length to crypt depth ratio with higher villus height is directly linked to increased absorption area and nutrient absorption. In addition, goblet cell concentration in intestinal villi is another gut health parameter because these cells reduce the chances of attachment of pathogenic bacteria to intestinal epithelium and enhance mucin production [63]. Probiotics have positive effects on gut histomorphology, but the degree of effectiveness may vary from strain to strain. As increase in villus height with decrease in crypt depth was observed in broilers fed probiotic containing L. acidophilus, L. casei, Enterococcus faecium, and Bifidobacterium thermophilum [17]. Similarly, supplementation of B. coagulans [64]; combination of L. acidophilus, L. casei, Enterococcus faecium and Bifidobacterium thermophilum, [65]; L. reuteri and L. salivarius [66]; Propionibacterium acidipropionici [67]; mixture of B. licheniformis, B. subtilis and S. cerevisiae [68] and P. acidilactici
[69] in broilers exhibited positive effect on gut histomorphology with increased villus length and villus length to crypt depth ration which suggested that probiotics enhanced nutrient absorption.

Hayashi et al [70] fed B. subtilis to broilers and found improved histologic modification associated with stimulation of the defense reaction in the ileum. Most of the $L A B$ species affect the gut health positively. Chen et al [71] found significant reduction in Salmonella counts recovered from the cecal tonsils, spleens, and livers and Gao et al [25] observed accelerated maturation of intestinal microbiota by $L A B$ feeding in broilers. $L A B$ may be efficacious for reduction of $S$. enteritidis in young chicken [72]. Increased anaerobic bacteria in the ileum and caeca, and lactic acid bacteria and lactobacilli in the caeca with significant increase in weight of small intestinal (jejunum and ileum) was observed with $L A B$. Probiotics also reduced the count of pathogenic bacterial [37]. Palamidi et al [38] suggested that $L A B$ increased the digestibility of dry matter and fat in diet. $L A B$ significantly increased the number of beneficial bacteria one-week post feeding and reduced the count of pathogenic bacterial by 40 days post

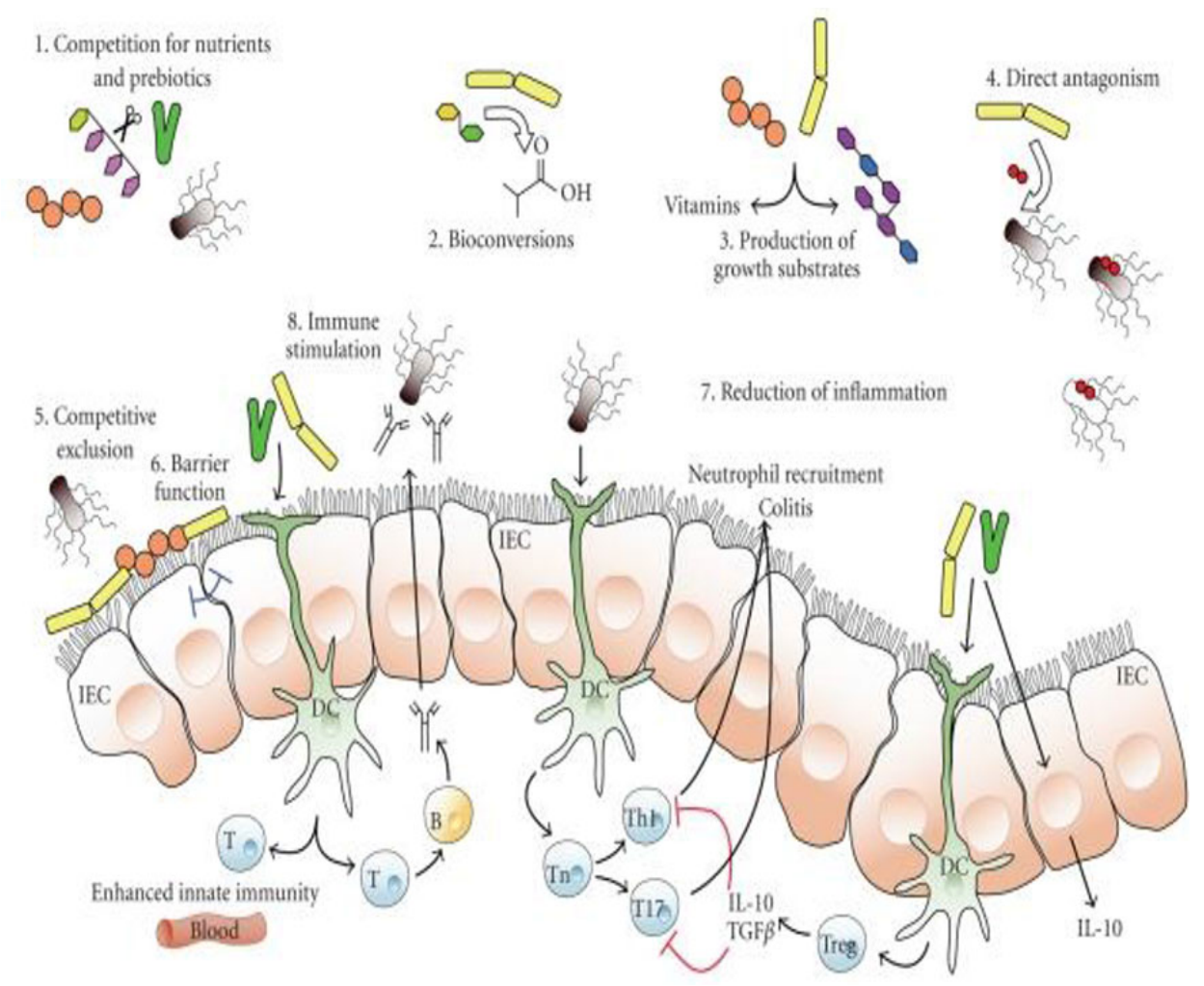

Figure 2. Diagram showing the potential impact of probiotic bacteria on microbiota. The schematic diagram showing mechanism: 1) competition for nutrients and prebiotics for growth, 2) bioconversion of nutrients into other substances with selective inhibitory properties against pathogens, 3) production of growth substances like vitamins for other bacterial organisms, 4) direct antagonism through antibacterial agents like bacteriocins, 5) competitive exclusion for binding sites, 6) barrier function, 7) lessening of inflammation, hence changing intestinal ecosystem for colonization, and 8) modulation of innate immunity. IEC, epithelial cells; T, T-lymphocytes; B, B-lymphocytes; DC, dendritic cells; T, T-cells; Th1, T helper type 1; T17, a subset of T helper cell that produce interleukin 17; Treg, T-regulatory cell; IL-10, interleukin 10; TGF $\beta$, transforming growth factor beta (adopted from https://www.customprobiotics.com/mechanisms-of-action). 
feeding in broilers [27]. It is suggested by researches that probiotic feeding increase the total count of beneficial bacteria in intestine and reduce the number of disease-causing bacteria [73,74]. Supplementation of B. subtilis alone or in combination with $S$. boulardii have a significantly positive effect on intestinal histopathology and microflora in broilers $[34,35]$ (Table 3).

\section{UPDATED ACTION MODE OF PROBIOTICS}

There are different mechanisms through which probiotics work to facilitate the host animals, which may include occupation of epithelial cells to avoid the colonization of pathogenic bacteria, stimulation of enzyme synthesis, production of some antimicrobial substances and reduction of toxin production, boost up the immunity and stress reduction [75] (Figure 3).

Occupation of the site of attachment in GIT by probiotics to avoid pathogenic bacteria could result in physical blocking of pathogen colonization. This physical blocking alters the environment of GIT and is beneficial for host animals to improve their immune system. This mechanism was found by Nurmi and Rantala [76], suggesting that Salmonella colonization in the GIT of newly hatched chicken could be reduced by feeding a suspension of gut contents of healthy adult chicken. In this way pathogenic bacteria are excluded from the site of replication. Probiotics also produce some antimicrobial sub-

Table 3. Effect of probiotics on gut health and microbiota of poultry

\begin{tabular}{|c|c|c|c|c|c|c|}
\hline $\mathrm{Sr}$ & Probiotic & Animal & Inclusion level & Duration & Gut health and microbiota & Reference \\
\hline 1 & L. plantarum strain IMAU10120 & Broiler & $2 \times 10^{6} \mathrm{cfu} / \mathrm{mL}$ & 42 days & $\begin{array}{l}\text { Accelerated maturation of intestinal micro- } \\
\text { biota, and stimulated the growth of many } \\
\text { intestinal Lactobacillus spp. }\end{array}$ & [25] \\
\hline 3 & S. boulardii and B. subtilis B10 & Broiler & $\begin{array}{l}1 \times 10^{8} \mathrm{cfu} / \mathrm{kg} \text { of } \\
\text { feed }\end{array}$ & 72 days & $\begin{array}{l}\text { Significant improvement in intestinal villus } \\
\text { height, width, and number of goblet cells }\end{array}$ & [34] \\
\hline 4 & B. subtilis C-3102 & Broiler & $0.1 \%$ of diet & 42 days & $\begin{array}{l}\text { Decreased crypt depth and increased villus } \\
\text { height with significant reduction in E. coli, } \\
\text { coliform, and Salmonella populations of ceca }\end{array}$ & {$[35]$} \\
\hline 5 & B. subtilis PB6 (ATCC-PTA 6737) & Broiler & $\begin{array}{l}5 \times 10^{11} \mathrm{cfu} / \mathrm{kg} \\
\text { feed }\end{array}$ & 35 days & $\begin{array}{l}\text { Significant reduction in intestinal C. perfrin- } \\
\text { gens counts, improved villi length and villi } \\
\text { length to crypt depth ratio }\end{array}$ & [36] \\
\hline 7 & $\begin{array}{l}\text { L. reuteri (DSM 16350), E. fae- } \\
\text { cium (DSM 16211), B. animals } \\
\text { (DSM 16284), P. acidilactici (DSM } \\
\text { 16210) and L. salivarius (DSM } \\
\text { 16351) }\end{array}$ & Broiler & $10^{8} \mathrm{cfu} / \mathrm{kg}$ diet & 42 days & $\begin{array}{l}\text { Significant improvement in total tract ap- } \\
\text { parent digestibility of crude protein, fats and } \\
\text { ileal digestibility of dry matter }\end{array}$ & [38] \\
\hline \multirow[t]{2}{*}{8} & $\begin{array}{l}\text { Blend of } 3 \text { Bacillus substilis } \\
\text { strains }\end{array}$ & Broiler & $7.5 \times 10^{4} \mathrm{cfu} / \mathrm{g}$ & 21 days & $\begin{array}{l}\text { Both reduced the apparent ileal digestibility } \\
\text { of dry matter and crude protein }\end{array}$ & [58] \\
\hline & P. acidipropionici (PA) & & & & & \\
\hline \multirow[t]{2}{*}{9} & Lactobacillus spp. & Broiler & $1 \mathrm{~g} / \mathrm{kg}$ feed & 35 days & $\begin{array}{l}\text { Increased the birds' resistance to Eimeria } \\
\text { acervuline }\end{array}$ & {$[61]$} \\
\hline & B. subtilis & Broiler & 250 , or $500 \mathrm{~g} /$ ton & 21 days & $\begin{array}{l}\text { Higher dose improves the defense response } \\
\text { in the ileum }\end{array}$ & [70] \\
\hline 13 & L. salivarius & Broiler & $\begin{array}{l}10^{8} \text { cfu } 100 \mu \mathrm{L} \text { of } \\
\text { phosphate-buff- } \\
\text { ered saline }\end{array}$ & 14 days & $\begin{array}{l}\text { Lower the number of } C \text {. perfringens and } S \text {. } \\
\text { enteritidis in the gut }\end{array}$ & [74] \\
\hline
\end{tabular}

cfu, colony forming unit. 


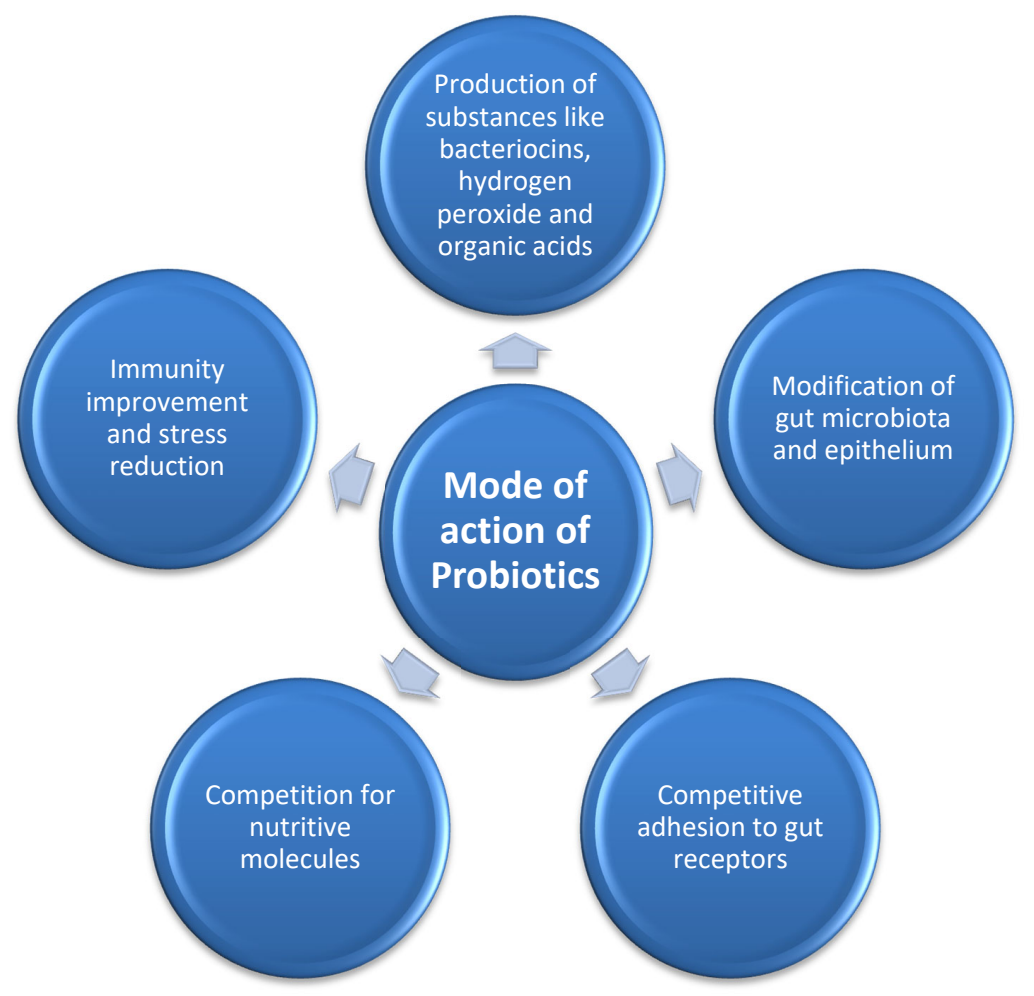

Figure 3. Showing mode of action of probiotics that results improved production performance in monogastric animals by producing many gut microbiota modulating factors (like bacteriocins, organic acids etc) that improve immunity, reduce stress, improve nutrient production and utilization and modulate competitive adhesion to gut.

stances like bacteriocins, hydrogen peroxide and organic acids [77]. Organic acids decrease the $\mathrm{pH}$ of intestine which helps absorption of minerals (calcium, iron, copper, magnesium, and manganese) and protein. Probiotics help to regenerate intestinal mucosa, upregulate the mucous production and intestinal motility, modulate host immune system by stimulation of antibody production and natural killer cells [77], and improve the digestion by increasing the secretions of digestive enzymes. Probiotics can also reduce the blood cholesterol level by virtue of their bile salt hydrolase activity which lower the chances of cardiovascular disease [78]. There is another mode of action in probiotics called cross feeding, which means feeding of one bacteria is beneficial for another bacteria production. For example, lactic acid produced by lactic acid producing bacteria can be used by butyric acid producing bacteria and produce a large amount of butyric acid [79]. The cross-feeding mechanism of butyric acid production is beneficial to enhance the growth performance.

\section{CONCLUSION}

Keeping in view the past studies, it could be concluded that probiotics could be serve as growth promoters because they improve the gut health which ultimately improves the nutri- ent digestibility by enhancing the digestive enzyme activities and improves the growth performance and meat quality. Probiotics also modulate the immune response in such a way to protect host animals from pathogenic disease, in addition through competitive exclusion mechanism they protect the host animals from colonization by pathogenic bacteria. Inconsistency in results could be due to numerous biotic and abiotic factors which could be resolved by further studies concerning detail of mode of action, mode of delivery and improving probiotic in vivo efficacy.

\section{CONFLICT OF INTEREST}

We certify that there is no conflict of interest with any financial organization regarding the material discussed in the manuscript.

\section{FUNDING}

This work was financially supported by "The National Key Research and Development Program of China" under grant number (2018YFE0112700) and "The Science and Technology Key Projects of Zhejiang Province, China" under grant number (2019C02005). 


\section{REFERENCES}

1. Boamah VE, Agyare C, Odoi H, Dalsgaard A. Antibiotic practices and factors influencing the use of antibiotics in selected poultry farms in Ghana. J Antimicrob Agents 2016; 2:1000120. https://doi.org/10.4172/2472-1212.1000120

2. Peterson E, Kaur P. Antibiotic resistance mechanisms in bacteria: Relationships between resistance determinants of antibiotic producers, environmental bacteria, and clinical pathogens. Front Microbiol 2018;9:2928. https://doi.org/10. 3389/fmicb.2018.02928

3. Marshall BM, Levy SB. Food animals and antimicrobials: Impacts on human health. Clin Microbiol Rev 2011;24:71833. https://doi.org/10.1128/CMR.00002-11

4. Grenni P, Ancona V, Caracciolo AB. Ecological effects of antibiotics on natural ecosystems: a review. Microchem J 2018;136:25-39. https://doi.org/10.1016/j.microc.2017.02. 006

5. Davies J. Microbes have the last word. A drastic re-evaluation of antimicrobial treatment is needed to overcome the threat of antibiotic-resistant bacteria. EMBO Rep 2007;8:616-21. https://doi.org/10.1038/sj.embor.7401022

6. Bassetti M, Merelli M, Temperoni C, Astilean A. New antibiotics for bad bugs: where are we? Ann Clin Microbiol Antimicrob 2013;28:12:22. https://doi.org/10.1186/14760711-12-22

7. Mamza SA, Egwu GO, Mshelia GD. Beta-lactamase Escherichia coli and Staphylococcus aureus isolated from chickens in Nigeria. Vet Ital 2010;46:155-65.

8. Boamah VE, Agyare C, Odoi H, Adu F, Gbedema S, Dalsgaard A. Prevalence and antibiotic resistance of coagulase-negative Staphylococci isolated from poultry farms in three regions of Ghana. Infect Drug Resist 2017;10:175-83. https://doi.org/ 10.2147/IDR.S136349

9. Suleiman A, Zaria LT, Grema HA, Ahmadu P. Antimicrobial resistant coagulase positive Staphylococcus aureus from chickens in Maiduguri, Nigeria. Sokoto J Vet Sci 2013;11: 51-5. https://doi.org/10.4314/sokjvs.v11i1.8

10. Odoi H. Isolation and characterization of multi-drug resistant pseudomonas aeruginosa from clinical, environmental and poultry litter sources in Ashanti Region of Ghana [Thesis]. Kumasi, Ghana: Kwame Nkrumah University of Science and Technology; 2016.

11. Sharma S, Galav V, Agrawal M, Faridi F, Kumar B. Multi-drug resistance pattern of bacterial flora obtained from necropsy samples of poultry. J Anim Health Prod 2017;5:165-71. https:// doi.org/10.17582/journal.jahp/2017/5.4.165.171

12.van den Bogaard AE, Stobberingh EE. Epidemiology of resistance to antibiotics: Links between animals and humans. Int J Antimicrob Agents 2000;14:327-35. https://doi.org/10. 1016/s0924-8579(00)00145-x

13. Medeiros MAN, de Oliveira DCN, Rodrigues DP, de Freitas
DRC. Prevalence and antimicrobial resistance of Salmonella in chicken carcasses at retail in 15 Brazilian cities. Rev Panam Salud Publica 2011;30:555-60. https://doi.org/10.1590/s102049892011001200010

14. Wilson IG. Antibiotic resistance of Campylobacter in raw retail chickens and imported chicken portions. Epidemiol Infect 2003;131:1181-6. https://doi.org/10.1017/s0950268803 001298

15. Castanon JIR. History of the use of antibiotic as growth promoters in European poultry feeds. Poult Sci 2007;86:246671. https://doi.org/10.3382/ps.2007-00249

16. Arora M, Baldi A. Regulatory categories of probiotics across the globe: A review representing existing and recommended caterorization. Indian J Med Microbiol 2015;33:S2-S10. https:// doi.org/10.4130/0255-0857.1508686

17. Alagawany M, Abd El-Hack ME, Farag MR, Sachan S, Karthik $\mathrm{K}$, Dhama K. The use of probiotics as eco-friendly alternatives for antibiotics in poultry nutrition. Environ Sci Pollut Res 2018;25:10611-8. https://doi.org/10.1007/s11356-018-1687-x

18. Coman MM, Mazzotti L, Silvi S, et al. Antimicrobial activity of SYNBIO ${ }^{\circ}$ probiotic formulation in pathogens isolated from chronic ulcerative lesions: in vitro studies. J Appl Microbiol 2020;128:584-97. https://doi.org/10.1111/jam.14482

19. Angelakis $\mathrm{E}$. Weight gain by gut microbiota manipulation in productive animals. Microb Pathog 2017;106:162-70. https:// doi.org/10.1016/j.micpath.2016.11.002

20. Gadde UD, Kim WH, Oh ST, Lillehoj HS. Alternatives to antibiotics for maximizing growth performance and feed efficiency in poultry: a review. Anim Health Res Rev 2017;18: 26-45. https://doi.org/10.1017/S1466252316000207

21. Ferreira CL, Salminen S, Grzeskowiak L, et al. Terminology concepts of probiotic and prebiotic and their role in human and animal health. Rev Salud Anim 2011;33:137-46.

22. Klose V, Mohnl M, Plail R, Schatzmayr G, Loibner AP. Development of a competitive exclusion product for poultry meeting the regulatory requirements for registration in the European Union. Mol Nutr Food Res 2006;50:563-7. https://doi.org/ 10.1002/mnfr.200500166

23. Jiang T, Li HS, Han GG, et al. Oral delivery of probiotics in poultry using $\mathrm{pH}$-sensitive tablets. J Microbiol Biotechnol 2017;27:739-46. https://doi.org/10.4014/jmb.1606.06071

24. Bajagai YS, Klieve AV, Dart PJ, Bryden WL. Animal production and health div probiotics. In: Animal nutrition: production, impact and regulation. Rome, Italy: Food and Agriculture Organization of the United Nations; 2016.

25. Gao P, Ma C, Sun Z, et al. Feed-additive probiotics accelerate yet antibiotics delay intestinal microbiota maturation in broiler chicken. Microbiome 2017;5:91. https://doi.org/10.1186/s40 168-017-0315-1

26. Khan M, Raoult D, Richet H, Lepidi H, La Scola B. Growthpromoting effects of single-dose intragastrically administered probiotics in chickens. Br Poult Sci 2007;48:732-5. https:// 
doi.org/10.1080/00071660701716222

27.Lan PT, Binh le T, Benno Y. Impact of two probiotic Lactobacillus strains feeding on fecal lactobacilli and weight gains in chicken. J Gen Appl Microbiol 2003;49:29-36. https://doi. org/10.2323/jgam.49.29

28. Alkhalf A, Alhaj M, Al-homidan I. Influence of probiotic supplementation on blood parameters and growth performance in broiler chickens. Saudi J Bio Sci 2010;17:219-25. https://doi.org/10.1016/j.sjbs.2010.04.005

29. Wang X, Farnell YZ, Peebles ED, Kiess AS, Wamsley KG, Zhai W. Effects of prebiotics, probiotics, and their combination on growth performance, small intestine morphology, and resident Lactobacillus of male broilers. Poult Sci 2016;95:133240. https://doi.org/10.3382/ps/pew030

30. Kabir SML, Rahman MM, Rahman MB, Rahman MM, Ahmed SU. The dynamics of probiotics on growth performance and immune response in broilers. Int J Poult Sci 2004;3:361-4. https://doi.org/10.3923/ijps.2004.361.364

31. Bai SP, Wu AM, Ding XM, et al. Effects of probiotic-supplemented diets on growth performance and intestinal immune characteristics of broiler chickens. Poult Sci 2013;92:663-70. https://doi.org/10.3382/ps.2012-02813

32. Capcarova M, Weis J, Hrncar C, Kolesarova A, Pal G. Effect of Lactobacillus fermentum and Enterococcus faecium strains on internal milieu, antioxidant status and body weight of broiler chickens. J Anim Physiol Anim Nutr 2010;94:e21524. https://doi.org/10.1111/j.1439-0396.2010.01010.x

33. Hatab MH, Elsayed MA, Ibrahim NS. Effect of some biological supplementation on productive performance, physiological and immunological response of layer chicks. J Radiat Res Appl Sci 2016;9:185-92. https://doi.org/10.1016/j.jrras.2015. 12.008

34. Rajput IR, Li LY, Xin X, et al. Effect of Saccharomyces boulardii and Bacillus subtilis B10 on intestinal ultrastructure modulation and mucosal immunity development mechanism in broiler chickens. Poult Sci 2013;92:956-65. https://doi.org/10.3382/ ps.2012-02845

35. Manafi M, Khalaji S, Hedayati M, Pirany N. Efficacy of Bacillus subtilis and bacitracin methylene disalicylate on growth performance, digestibility, blood metabolites, immunity, and intestinal microbiota after intramuscular inoculation with Escherichia coli in broilers. Poult Sci 2017;96:1174-83. https:// doi.org/10.3382/ps/pew347

36.Jayaraman S, hangavel G, Kurian H, Mani R, Mukkalil R, Chirakkal H. Bacillus subtilis PB6 improves intestinal health of broiler chickens challenged with Clostridium perfringensinduced necrotic enteritis. Poult Sci 2013;92:370-4. https:// doi.org/10.3382/ps.2012-02528

37. Olnood CG, Sleman SMB, Choct M, Iji PA. Novel probiotics: Their effects on growth performance, gut development, microbial community and activity of broiler chickens. Anim Nutr 2015;1:184-91. https://doi.org/10.1016/j.aninu.2015.
07.003

38. Palamidi I, Fegeros K, Mohnl M, et al. Probiotic form effects on growth performance, digestive function, and immune related biomarkers in broilers. Poult Sci 2016;95:1598-608. https://doi.org/10.3382/ps/pew052

39. Faria-Filho DE, Torres KAA, Faria DE, Campos DMB, Rosa PS. Probiotics for broiler chickens in Brazil: systematic review and meta-analysis. Braz J Poult Sci 2006;8:89-98. https://doi. org/10.1590/S1516-635X2006000200004

40. Blajman JE, Frizzo LS, Zbrun MV, et al. Probiotics and broiler growth performance: a meta-analysis of randomized controlled trials. Br Poult Sci 2014;55:483-94. https://doi.org/ 10.1080/00071668.2014.931930

41.Jensen JF, Jensen MM. The effect of using growth promoting Bacillus strains in poultry feed. In: Proceedings 19th World's Poultry Congress: 1992 Sept 18; Amsterdam, The Netherlands. WPSA;1992. Vol 3. pp. 398-402.

42.Loddi MM, Gonzalez E, Takita TS, Mendes AA, Roca RO. Effect of the use of probiotic and antibiotic on the performance, yield and carcass quality of broilers. Rev Bras Zootec 2000;29:1124-31.

43. Mahajan P, Sahoo J, Panda PC. Effect of probiotic (LactoSacc) feeding, packaging methods and seasons on the microbial and organoleptic qualities of chicken meat balls during refrigerated storage. J Food Sci Technol 2000;37:67-71.

44.Pelicano ERL, Souza PA, De Souza HBA, et al. Effect of different probiotics on broiler carcass and meat quality. Rev J Port Sci 2003;5:207-14. https://doi.org/10.1590/S1516-635 X2003000300009

45. Ceslovas J, Junka V, Simkus A. The effect of probiotics and phytobiotics on meat properties and quality in pigs. Vet Zootec 2005;29:80-4.

46. Sadeghi AA. Bone mineralization of broiler chicks challenged with salmonella enteritidis fed diet containing probiotic (Bacillus subtilis). Probiotics Antimicrob Proteins 2014;6:13640. https://doi.org/10.1007/s12602-014-9170-6

47.Gutierrez-Fuentes CE, Zuniga-Orozco LA, Vicente JL, et al. Effect of a lactic acid bacteria based probiotic, FloraMax-B11 ${ }^{\circ}$, on performance, bone qualities and morphometric analysis of broiler chickens: an economic analysis. Int J Poult Sci 2013;12:322-7. https://doi.org/10.3923/ijps.2013.322.327

48. Mutus R, Kocabagli N, Alp M, Acar N, Eren M, Gezen SS. The effect of dietary probiotic supplementation on tibial bone characteristics and strength in broilers. Poult Sci 2006; 85:1621-5. https://doi.org/10.1093/ps/85.9.1621

49.Panda AK, Rao SVR, Raju MV, Sharma SR. Dietary supplementation of Lactobacillus sporogenes on performance and serum biochemico-lipid profile of broiler chickens. J Poult Sci 2006;43:235-40. https://doi.org/10.2141/jpsa.43.235

50. Houshmand M, Azhar K, Zulkifli I, Bejo MH, Meimandipour A, Kamyab A. Effects of non-antibiotic feed additives on performance, tibial dyschondroplasia incidence and tibia 
characteristics of broilers fed low-calcium diets. J Anim Physiol Anim Nutr 2011;95:351-8. https://doi.org/10.1111/ j.1439-0396.2010.01061.x

51.Abdelqader A, Al-Fataftah AR, Das G. Effects of dietary Bacillus subtilis and inulin supplementation on performance, eggshell quality, intestinal morphology and microflora composition of laying hens in the late phase of production. Anim Feed Sci Technol 2013;179:103-11. https://doi.org/10.1016/ j.anifeedsci.2012.11.003

52. Abdelqader A, Irshaid R, Al-Fataftah AR. Effects of dietary probiotic inclusion on performance, eggshell quality, cecal microflora composition, and tibia traits of laying hens in the late phase of production. Trop Anim Health Prod 2013; 45:1017-24. https://doi.org/10.1007/s11250-012-0326-7

53.Zhang JL, Xie QM, Ji J, et al. Different combinations of probiotics improve the production performance, egg quality, and immune response of layer hens. Poult Sci 2012;91:275560. https://doi.org/10.3382/ps.2012-02339

54.El-Gawad IAA, Mehriz AEM, Saleh FA, Rayan EA. Bioavailability of $\mathrm{Ca}, \mathrm{P}$ and $\mathrm{Zn}$ and Bone Mineralization in Rats Fed Yoghurt and Soy-yoghurt Containing Bifidobacteria. Eur J Nutr Food Saf 2014;4:110-26. https://doi.org/10.9734/EJNFS/ 2014/6856

55. Ghosh K, Ray M, Adak A, et al. Role of probiotic Lactobacillus fermentum KKL1 in the preparation of a rice based fermented beverage. Bioresour Technol 2015;188:161-8. https:/doi.org/ 10.1016/j.biortech.2015.01.130

56.Suvarna VC, Boby VU. Probiotics in human health: a current assessment. Curr Sci 2005;88:1744-8. https://www.jstor.org/ stable/24110346

57.Haghighi HR, Abdul-Careem MF, Dara RA, Chambers JR, Sharif S. Cytokine gene expression in chicken cecal tonsils following treatment with probiotics and Salmonella infection. Vet Microbiol 2008;126:225-33. https://doi.org/10.1016/j. vetmic.2007.06.026

58. Waititu SM, Yitbarek A, Matini E, et al. Effect of supplementing direct-fed microbials on broiler performance, nutrient digestibilities, and immune responses. Poult Sci 2014;93:625-35. https://doi.org/10.3382/ps.2013-03575

59. Beirão BC, Ingberman M, Fávaro Jr, C. et al. Effect of an Enterococcus faecium probiotic on specific IgA following live Salmonella Enteritidis vaccination of layer chickens. Avian Pathol 2018;47:325-33. https://doi.org/10.1080/0307 9457.2018.1450487

60. Haghighi HR, Gong J, Gyles CL, et al. probiotics stimulate production of natural antibodies in chickens. Clin Vaccine Immunol 2006;13:975-80. https://doi.org/10.1128/CVI.0016106

61.Dalloul RA, Lillehoj HS, Shellem TA, Doerr JA. Enhanced mucosal immunity against Eimeria acervulina in broilers fed a lactobacillus-based probiotic. Poult Sci 2003;82:62-6. https://doi.org/10.1093/ps/82.1.62
62. Khalique A, Zeng D, Shoaib M, et al. Probiotics mitigating subclinical necrotic enteritis (SNE) as potential alternatives to antibiotics in poultry. AMB Express 2020;10:50. https:// doi.org/10.1186/s13568-020-00989-6

63. Shroyer NF, Kocoshis SA. Anatomy and physiology of the small and large intestines. In: Pediatric gastrointestinal and liver disease. Amsterdam, The Netherlands: Elsevier; 2011. pp. 324-36. https://doi.org/10.1016/B978-1-4377-0774-8. 10031-4

64.Zhen W, Shao Y, Gong X, et al. Effect of dietary Bacillus coagulans supplementation on growth performance and immune responses of broiler chickens challenged by Salmonella enteritidis. Poult Sci 2018;97:2654-2666. https://doi. org/10.3382/ps/pey119

65. Chichlowski M, Croom WJ, Edens FW, et al. Microarchitecture and spatial relationship between bacteria and ileal, cecal, and colonic epithelium in chicks fed a direct-fed microbial, PrimaLac, and Salinomycin. Poult Sci 2007;86:1121-32. https:// doi.org/10.1093/ps/86.6.1121

66. Messaoudi S, Manai M, Kergourlay G, et al. Lactobacillus salivarius: Bacteriocin and probiotic activity. Food Microbiol 2013;36:296-304. https://doi.org/10.1016/j.fm.2013.05.010

67.Martínez EA, Babot JD, Lorenzo-Pisarello MJ, Apella MC, Chaia AP. Feed supplementation with avian Propionibacterium acidipropionici contributes to mucosa development in early stages of rearing broiler chickens. Benef Microbes 2016;7:687-98. https://doi.org/10.3920/BM2016.0077

68. He T, Long S, Mahfuz S, et al. Effects of probiotics as antibiotics substitutes on growth performance, serum biochemical parameters, intestinal morphology, and barrier function of broilers. Animals 2019;9:985. https://doi.org/10.3390/ani 9110985

69. Jazi V, Foroozandeh AD, Toghyani M, Dastar B, Rezaie Koochaksaraie R, Toghyani M. Effects of Pediococcus acidilactici, mannan-oligosaccharide, butyric acid and their combination on growth performance and intestinal health in young broiler chickens challenged with Salmonella Typhimurium. Poult Sci 2018;97:2034-43. https://doi.org/10.3382/ps/pey035

70.Hayashi RM, Lourenço MC, Kraieski AL, et al. Effect of Feeding Bacillus subtilis Spores to broilers challenged with salmonella enterica serovar Heidelberg Brazilian strain UFPR1 on performance, immune response, and gut health. Front Vet Sci 2018;5:13. https://doi.org/10.3389/fvets.2018.00013

71.Chen CY, Tsen HY, Lin CL, Yu B, Chen CS. Oral administration of a combination of select lactic acid bacteria strains to reduce the Salmonella invasion and inflammation of broiler chicks. Poult Sci 2012;91:2139-47. https://doi.org/10.3382/ ps.2012-02237

72. Higgins SE, Higgins JP, Wolfenden AD, et al. Evaluation of a Lactobacillus-based probiotic culture for the reduction of Salmonella enteritidis in neonatal broiler chicks. Poult Sci 2008;87:27-31. https://doi.org/10.3382/ps.2007-00210 
73. Khaksefidi A, Rahimi SH. Effect of probiotic inclusion in the diet of broiler chickens on performance, feed efficiency and carcass quality. Asian-Australas J Anim Sci 2005;18: 1153-6. https://doi.org/10.5713/ajas.2005.1153

74. Kizerwetter-Swida M, Binek M. Protective effect of potentially probiotic Lactobacillus strain on infection with pathogenic bacteria in chickens. Pol J Vet Sci 2009;12:15-20.

75. Falcao-e-Cunha L, Castro-Solla L, Maertens L, et al. Alternatives to antibiotic growth promoters in rabbit feeding: a review. World Rabbit Sci 2007;15:127-40. https://doi.org/10. 4995/wrs.2007.597

76. Nurmi E, Rantala M. New aspects of Salmonella infection in broiler production. Nature 1973;241:210-1. https://doi.org/ $10.1038 / 241210 \mathrm{a} 0$
77.Tiwari G, Tiwari R, Pandey S, Pandey P. Promising future of probiotics for human health: Current scenario. Chron Young Sci 2012;3:17-28. https://doi.org/10.4103/2229-5186.94308

78. Jones ML, Tomaro-Duchesneau C, Martoni CJ, Prakash S. Cholesterol lowering with bile salt hydrolase-active probiotic bacteria, mechanism of action, clinical evidence, and future direction for heart health applications. Expert Opin Biol Ther 2013;13:631-42. https://doi.org/10.1517/14712598.201 3.758706

79. Duncan SH, Louis P, Flint HJ. Lactate-utilizing bacteria, isolated from human feces, that produce butyrate as a major fermentation product. Appl Environ Microbiol 2004;70:5810-5817. https://doi.org/10.1128/AEM.70.10.5810-5817.2004 